
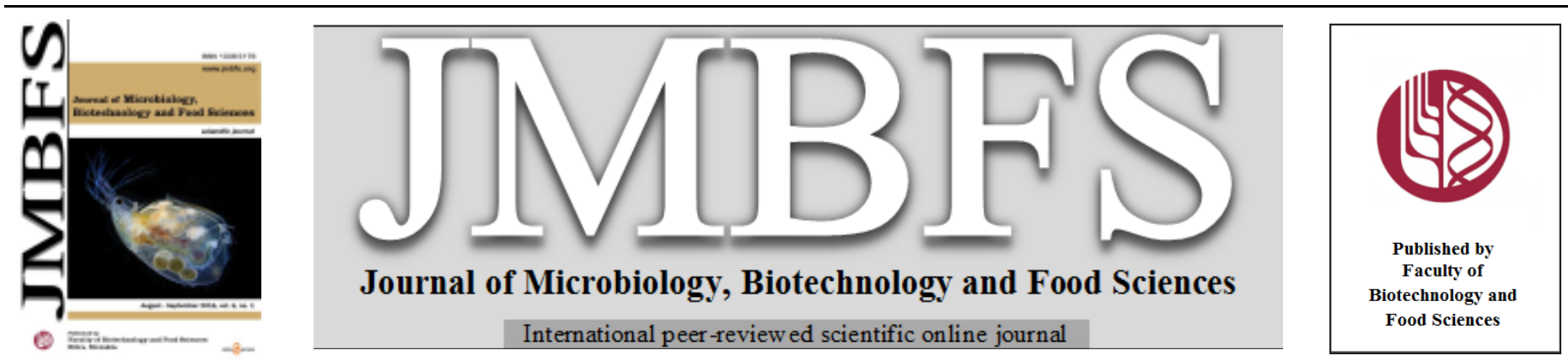

\title{
MODULATION OF DIGESTIVE ENZYMES AND LIPOPROTEIN METABOLISM BY ALPHA MANGOSTEEN EXTRACTED FROM MANGOSTEEN (GARCINIA MANGOSTANA) FRUIT PEELS
}

\author{
Shruti Mishra ${ }^{1 *}$ Maushmi S. Kumar ${ }^{2}$, Robert Cyril Stanley $H^{3}$, Anil K. Anal ${ }^{1}$ \\ Address(es): Ms. Shruti Mishra \\ ${ }^{1}$ Food Engineering and Bioprocess Technology, Asian Institute of Technology, PO Box 4, Klong Luang, Pathumthani 12120, Thailand. \\ ${ }^{2}$ Department of Pharmaceutical Biotechnology, Shobhaben Prataphhai Patel School of Pharmacy and Technology Management, SVKM'S NMIMS, Vile Parle (west), \\ Mumbai- 400056 . \\ ${ }^{3}$ G7 Synergon Private Limited, Sahakara Nagar, Tatanagar, Sahakara Nagar, Bengaluru, Karnataka 560054.
}

*Corresponding author: shrutimishra.ait@ gmail.com

doi: 10.15414/jmbfs.2016.6.1.717-721

ARTICLE INFO

Received 16. 7. 2015

Revised 20. 4. 2016

Accepted 21. 4. 2016

Published 1. 8. 2016

Regular article

open $\partial$ ACCESS

\begin{abstract}
The present work deals with the potential of Garcinia mangostana L. (Mangosteen, Clusiaceae) for modulation of digestive and plasma lipid transfer protein as an approach to discover novel inhibitors. Garcinia mangostana (in methanol, dicholromethane and hexane) extracts were screened for alpha amylase, alpha glucosidase and Cholesteryl ester transfer protein (CETP) inhibition assays. TLC, HPLC, LC-MS analysis were performed and was compared with reference standard. Alpha amylase results obtained were $39.4 \mu \mathrm{g} / \mathrm{ml}$, $11.87 \mu \mathrm{g} / \mathrm{ml}$ and $9.048 \mu \mathrm{g} / \mathrm{ml}$ respectively. For CETP inhibition assay the dose response was done only for the hexane extract as others were not showing potent inhibition. Thus an $\mathrm{IC}_{50}$ of $10.89 \mu \mathrm{g} / \mathrm{ml}$ was obtained and the hexane extract was taken for further analysis to discover the compound responsible for the activity. Alpha mangosteen was found to be the active compound in Garcinia mangostana responsible for the potent inhibitor activity of alpha amylase and CETP enzyme in plant raw material.
\end{abstract}

Keywords: $\alpha$-mangosteen, $\alpha$-amylase, $\alpha$-glucosidase, CETP inhibition, LC-MS

\section{INTRODUCTION}

Naturally available plant materials including herbs, food-processing by-products, contain active compounds, which have numerous health benefits. The identification of active ingredients and the mechanism of their action are very important to understand their health benefits. Some of these phytochemicals have been found to inhibit particular enzymes to treat specific disease. Bioactive molecules from plant sources having ability to inhibit the activity of digestive enzymes are targeted as preventative measures. Not only digestive enzymes but also metabolic enzymes, which catalyze the biochemical reactions taking place in body, are now the new and emerging trends to be evaluated for the specific diseases. For example, cholesteryl ester transfer protein is a metabolic enzyme, which facilitates the transfer of cholesteryl esters (CE) from high-density lipoprotein (HDL) to low-density lipoprotein (LDL) in exchange of triglycerides. Some plant-based food compounds, such as berry polyphenols are reported as having amylase inhibition activity (McDougall $\boldsymbol{e t}$ al., 2005). There is still lack of research and report to prove the efficiency of compounds directly by cholesteryl ester transfer protein assay. Thus, there is need of exploring the novel inhibitors of such enzymes would definitely provide consumers a wide range of options to consume as food product and also for its disease preventing health benefits.

The present study deals with the exploration of such novel enzyme modulators, which are from natural plant sources. The phytochemicals which are responsible for the health benefits coming from plant sources are of considerable interest due to their wide range of physiological properties like antiallergenic, antiartherogenic, anti-inflammatory, antimicrobial, antioxidant, antithrombotic and cardio protective effects. Phytochemicals especially phenolic compounds have been reported to have many benefits on human health due to their presence in fruits and vegetables in high levels. Zadernowski $\boldsymbol{e t ~ a l . ~ ( 2 0 0 9 ) ~ d e t e r m i n e d ~ t h e ~}$ composition of phenolic acids in various parts of mangosteen fruit (Garcinia mangostana) by GC-MS. Based on the traditional uses, certain plant extracts were selected which have already been reported for antioxidant, antidiabetic, antihyperlipidemic activities such as leaves of Camellia sinensis, Azadirachta indica, pericarp of Garcinia mangostana and rhizome of Zingiber cassumunar (Ghasemzadeh et al. 2010, Mary et al. 2012). These plant extracts were selected due to their physiological properties and were hypothesized to be potential inhibitors of digestive and metabolic enzyme. The overall objective of the present study was to discover novel inhibitors of metabolic and digestive enzymes with the help of certain biochemical assays.

Garcinia mangostana, known as "Queen of fruits" is mostly found in India, Sri Lanka, Myanmar, Malaysia, Philippines and Thailand. The pericarp of the fruit contains $5.5 \%(\mathrm{w} / \mathrm{w})$ tannin resin and a yellow crystalline bitter principle compound, later named as mangosteen and chemical formula is $\mathrm{C}_{20} \mathrm{H}_{22} \mathrm{O}_{5}$ (Nadkarni \& Nadkarni, 1999). Xanthones from mangosteen fruit have been found to have significant biological activities such as antibacterial, anti-inflammatory, antioxidants, antitumoral, antifungal, antiallergic, and antiviral etc. (Suksamrarn et al., 2006). Garcinone E, Alpha mangosteen, Beta mangosteen, Gamma mangosteen and gartanin are the important xanthones present in mangoteen fruit. The bioactive compounds from the fruit also positively affect lipid profile of plasma and also antioxidant activity in rats which are fed with cholesterolcontaining diets (Leontowicz et al., 2007). Garcinone E, mangostinone, alpha, beta and gamma mangosteens, gartanin, 1,7-dihydroxy-2-(3-methylbut-2-enyl)-3methoxyxanthone) and 1,5-dihydroxy-2-(3-methylbut-2-enyl)-3methoxyxanthone were isolated from pericarps of mangosteen fruit (Asai et al. 1995). A new polyoxygenated xanthone, mangostanol and other known xanthones gartanin, $\alpha$-mangostin, 8 deoxygartanin, $\gamma$-mangostin, 5,9-dihydroxy2,2-dimethyl-8-methoxy-7-(3-methylbut-2-enyl)-2H,6H-pyrano[3,2-b]xanthen-6one,2-( $\gamma, \gamma$-dimethylallyl)-1,7-dihydroxy-3- ethoxyxanthone, garcinone $\mathrm{E}$, and epicatechin were also isolated from mangosteen fruit hulls (Chairungsrilerd $\boldsymbol{e} t$ al., 1996). Mangostenol, mangostenone and mangostenone $B$, three new xanthones along with the known xanthones $\alpha$-mangosteen, trapezifolixanthone, garcinone $\mathrm{B}$, tovophyllin $\mathrm{B}$, beta mangosteen, mangostinone, mangostanol and flavonoid epicatechin were also isolated from mangosteen fruit hulls (Suksamrarn et al., 2002). Four new compounds garcimangosone A, garcimangosone $\mathrm{B}$ and garcimangosone $\mathrm{C}$, also a benzophenone glucoside, garcimangosone $\mathrm{D}$ were also isolated (Huang et al., 2001).

\section{MATERIALS AND METHODS}

\section{Materials}

Garcinia mangostana (Mangosteen fruit) was procured from local market at Pathumthani, Thailand. Other plant materials were collected from G7 Synergon Ltd, Bangalore, India. Raw materials were cleaned; pericarp was separated from 
edible pulp for Mangosteen fruit. Pericarp was dried at $50^{\circ} \mathrm{C}$ in hot air oven for 10-12 hrs. Dried samples (< $10 \%$ M.C.) were ground in Tefal food processor (Hong Kong) until fine powder, stored in air tight containers in dark at room temperature $\left(25 \pm 2{ }^{\circ} \mathrm{C}\right)$ for further analysis. Alpha amylase enzyme (Type VI B from porcine pancreas from Sigma), 2-chloro-4-nitrophenol- $\alpha$-D-maltotrioside, acarbose, sodium dihydrogen orthophosphate and disodium hydrogen phosphate dihydrate (from Hi Media). Dimethyl sulphoxide was obtained from Sigma Aldrich. CETP Inhibitor Drug Screening Kit (Bio Vision) was procured from Gila Laboratories, Bangalore, India.

\section{Preparation of crude extract}

Hexane, dicholromethane and methanol were used to extract the bioactives from Garcinia mangostana, $20 \mathrm{~g}$ of the powdered sample was extracted in $100 \mathrm{~mL}$ of each of the mentioned solvents. Methanol and hexane extraction was carried out at $55^{\circ} \mathrm{C}$ and with dichloromethane at $37^{\circ} \mathrm{C}$ for 5 hours using an orbital shaker at $60 \mathrm{rpm}$. Mixture was further centrifuged at $10000 \mathrm{rpm}$, for 10 mins. Supernatant was collected and filtered using $0.45 \mu \mathrm{m}$ membrane filters and evaporated to near dryness. Residue then collected was weighed and stored at $4{ }^{\circ} \mathrm{C}$ for further use in assay.

\section{Preparation of rat intestinal mucosa}

The research was conducted in accordance with the internationally accepted principles for laboratory animal use and care as found in Committee for the Purpose of Control and Supervision of Experiments on Animals (CPCSEA), Ministry of Social Justice and Empowerment, Govt. of India. Sprague Dawley rats $(\mathrm{N}=2)$ were sacrificed and their intestine was separated and chilled with ice cold phosphate buffer $(80 \mathrm{mM}, \mathrm{pH}$ 7.0). Rat's intestinal mucosa was homogenized with four parts of ice-cold phosphate buffer $(80 \mathrm{mM}, \mathrm{pH} 7.0)$. Tube was chilled with ice and kept for homogenization for $10 \mathrm{~min}$. Large cell debris and nuclei like materials were separated by centrifugation In an eppendorf centrifuge at $10,000 \mathrm{rpm}$ for $10 \mathrm{~min}$ maintained at $4^{\circ} \mathrm{C}$ and finally the supernatant was collected and stored at $-20^{\circ} \mathrm{C}$ until further use (Leontowicz et al., 2007).

\section{Digestive and metabolic enzymes assay}

\section{$\alpha$-amylase assay}

Extract was dissolved in methanol and was diluted with phosphate buffer $(\mathrm{pH}$ 6.9) to obtain various concentrations ranging from $1-200 \mu \mathrm{g} / \mathrm{ml}$. The inhibitory activity of sample was assayed using procine pancreatic $\alpha$-amylase, Type VI-B enzyme and 2-chloro-4-nitrophenol- $\alpha$-D-maltotrioside (CNPG-3 reagent) as a substrate. Phosphate buffer $(40 \mu 1,40 \mathrm{mM}, \mathrm{pH} 6.9)$ along with the test sample (1$200 \mu \mathrm{g} / \mathrm{ml})$, reference standard $(0.1-10 \mu \mathrm{g} / \mathrm{ml})$ and $20 \mu \mathrm{l}$ enzyme was pre incubated at $37^{\circ} \mathrm{C}$ for 10 mins. $80 \mu \mathrm{l}$ substrate reagent (CNPG3) was added and incubated at $37^{\circ} \mathrm{C}$ for 8 mins in a 96 well plate and absorbance was read at 405 nm. A control reaction was also carried out without the test sample. The following formula was used to calculate the Inhibition \%

Inhibition $(\%)=\{$ Control absorbance - Test absorbance $\} \times 100$

Plot of percentage inhibition against the sample concentration was plotted and a logarithmic regression curve was established to calculate the $\mathrm{IC}_{50}$ value using Graph Pad Prism software. Half maximal inhibitory concentration $\left(\mathrm{IC}_{50}\right)$, represents the concentration of sample $(\mu \mathrm{g} / \mathrm{ml})$ necessary to decrease the activity of the enzyme by $50 \%$.

\section{$\alpha$ - Glucosidase activity of Mangosteen Extracts}

Extract was dissolved in methanol and further diluted with phosphate buffer $(\mathrm{pH}$ 7.0) to obtain various concentrations ranging from $1-200 \mu \mathrm{g} / \mathrm{ml}$. The inhibitory activity of sample was assayed using $\alpha$-glucosidase enzyme, isolated from rat intestinal mucosa and sucrose as a substrate. Phosphate buffer $(40 \mu 1,80 \mathrm{mM}, \mathrm{pH}$ 7.0) along with the test sample $(1-200 \mu \mathrm{g} / \mathrm{ml})$, reference standard $(0.1-10 \mu \mathrm{g} / \mathrm{ml})$ and $20 \mu \mathrm{l}$ enzyme was pre incubated at $37^{\circ} \mathrm{C}$ for $30 \mathrm{~min}$. The mixtures were incubated at $37^{\circ} \mathrm{C}$ for 20 mins after addition of sucrose solution $(100 \mu \mathrm{l})$. The reaction was arrested by heating in a boiling water bath and cooled. Sample (50 $\mu 1)$ was added with $100 \mu \mathrm{l}$ of glucose reagent from glucose reagent kit and incubated for $10 \mathrm{~min}$ at room temperature $\left(25^{\circ} \mathrm{C}\right)$, followed by measuring the absorbance at $510 \mathrm{~nm}$ (Tadera et al., 2006). A control reaction was carried out without the test sample. The following formula was used to calculate the Inhibition \%

Inhibition $(\%)=\{$ Control absorbance - Test absorbance $\} \times 100$

The $\mathrm{IC}_{50}$ values were calculated using Graph Pad Prism software as mentioned in

$\alpha$-amylase assay

\section{CETP inhibition activity of Mangosteen extracts}

The assay uses a donor molecule containing a fluorescent self-quenched neutra lipid that is transferred to an acceptor molecule In the presence of CETP (rabbit serum). CETP-mediated transfer of the fluorescent neutral lipid to the acceptor molecule results in an increase in fluorescence. Inhibitor of CETP will inhibit the lipid transfer and therefore decreases the fluorescence Intensity. Varying concentrations of the plant extracts ranging from $(10-200 \mu \mathrm{g} / \mathrm{mL})$ were used for the assay. Rabbit serum $(1.5 \mu \mathrm{l})$ was added as enzyme source to the test sample and kept for pre-incubation at $37^{\circ} \mathrm{C}$ for $10 \mathrm{~min}$. Master mix $(20 \mu \mathrm{l})$ containing 5 $\mu 1$ donor molecule, $5 \mu \mathrm{l}$ acceptor molecule and $10 \mu \mathrm{l}$ CETP assay buffer was added and remaining volume was made up with $20 \mu \mathrm{l}$ of buffer and kept for incubation at $37^{\circ} \mathrm{C}$ for $30 \mathrm{~min}$. Blank without rabbit serum and positive control containing rabbit serum, only without test inhibitors were also conducted. The samples were analyzed by Fluorescence spectrometer (excitation wavelength 465 $\mathrm{nm}$ and emission wavelength of $535 \mathrm{~nm}$ ) using a Tecan reader in a 96 well flat black microtiter plate.

\section{Identification of active compound}

\section{Thin Layer Chromatography (TLC)}

Screening of herbal products and their quality evaluations can be done easily with the help of standardized thin layer chromatographic techniques (Mohammad $\boldsymbol{e t}$ al., 2010). According to Mishra et al. (2009), quantitative estimation of alpha mangosteen can be done in fruit pericarp of Garcinia mangostana by using high performance thin layer chromatographic (HPTLC) method where methanol and chloroform was found to give highest and second highest recovery of alpha mangosteen, the bioactive xanthone. For our work, several solvent combinations were tried and optimized for separation of compounds in the extracts.

\section{High Performance liquid chromatography (HPLC) and Liquid} Chromatography Mass Spectrometry (LC-MS)

The separation of compounds was performed using HPLC 1200 (Agilent Technologies) with UV detector system. The reverse phase C18 Column (Phenomenex) was used, wavelength at $250 \mathrm{~mm}$. The mobile phase (80 acetonitrile: 20 water) was filtered through fine membranes (0.4-0.5 micron) and samples to be injected were dissolved in HPLC grade solvent DMSO and further diluted with methanol. The injection volume for all samples was $10 \mu 1$. The flow rate was $0.6 \mathrm{ml} / \mathrm{min}$, Total run time given was $45 \mathrm{~min}$ and detection was done at 210, 254, 310, 320 and $455 \mathrm{~nm}$. Mass analysis was done in Agilent Triple Quad 6410 LC MS-MS instrument from Agilent Technologies. In this case, mobile phase used was Acetonitrile and $0.1 \%$ acetic acid in the ratio of 70:30 (v/v)

\section{RESULTS AND DISCUSSION}

\section{$\alpha$ amylase inhibition assay}

Acarbose was taken as standard drug which is a prescribed $\alpha$ amylase inhibito for the treatment in Type 2 diabetes (Loo et al., 2007). Inhibition percentage for different conc. $(0.1-10 \mu \mathrm{g} / \mathrm{ml})$ of Acarbose was plotted on a nonlinear regression graph using graph pad prism software. Fig 1 illustrates the dose response curve, which has $\log$ of concentration of Acarbose on $\mathrm{X}$ axis and \% inhibition (dose response) on $\mathrm{Y}$ axis.

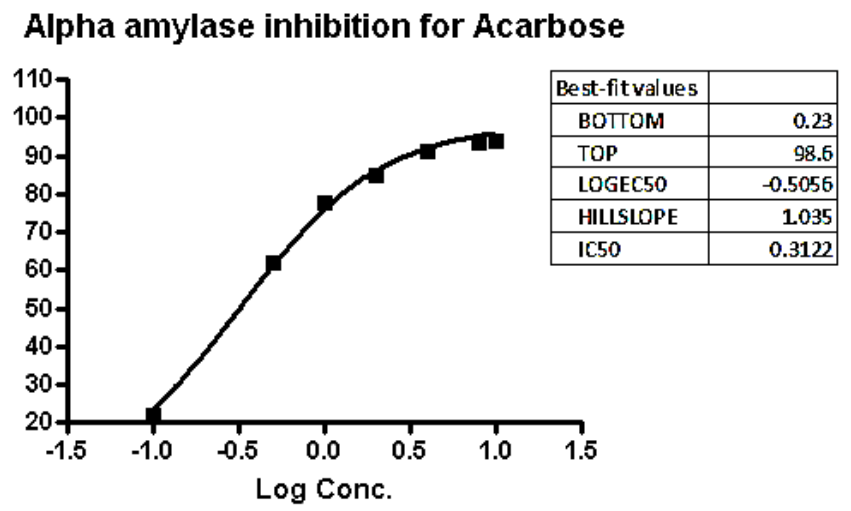

Figure 1 Dose response curve (Alpha Amylase Inhibition assay) for Reference standard Acarbose

The graph signifies the behavior of the curve at different concentrations of reference standard. An $\mathrm{IC}_{50}$ of $0.31 \mu \mathrm{g} / \mathrm{ml}$ was obtained. Acarbose has been proven as a very safe drug and a prescribed medication to treat Type 2 diabetes (Mertes, 2001). Thus the natural sources of alpha amylase inhibitors can be compared with this reference to prove their inhibitory activities. 
The methanolic, dichloromethane and hexane extract of Garcinia mangostana were analyzed for the alpha amylase inhibition assay at concentrations of (10100) $\mu \mathrm{g} / \mathrm{ml}$. Methanol (1\% v/v) was used as vehicle control. Percentage of inhibition was calculated using the equation:

$$
\% \text { Inhibition }=\{(\text { Control OD }- \text { Test OD }) / \text { Control OD }\} * 100
$$

The percentage inhibition plotted against log of concentration of the dose gave an $\mathrm{IC}_{50}$ of $39.4 \mu \mathrm{g} / \mathrm{ml}, 11.87 \mu \mathrm{g} / \mathrm{ml}$ and $9.05 \mu \mathrm{g} / \mathrm{ml}$ for methanol, dicholromethane and hexane extract respectively of Garcinia mangostana. Fig 2 illustrates the dose response curves for all the three extracts of Garcinia mangostana. The percentage inhibition was found increasing with the increased concentration of extracts. The three extracts are showing different results with the most potent activity found in the hexane extract having $\mathrm{IC}_{50}$ of $9.05 \mu \mathrm{g} / \mathrm{ml}$ which is slightly more potent than $\mathrm{IC}_{50}$ of dichloromethane extract which is $11.87 \mu \mathrm{g} / \mathrm{ml}$. The results reflect that the active compound is of non-polar nature.
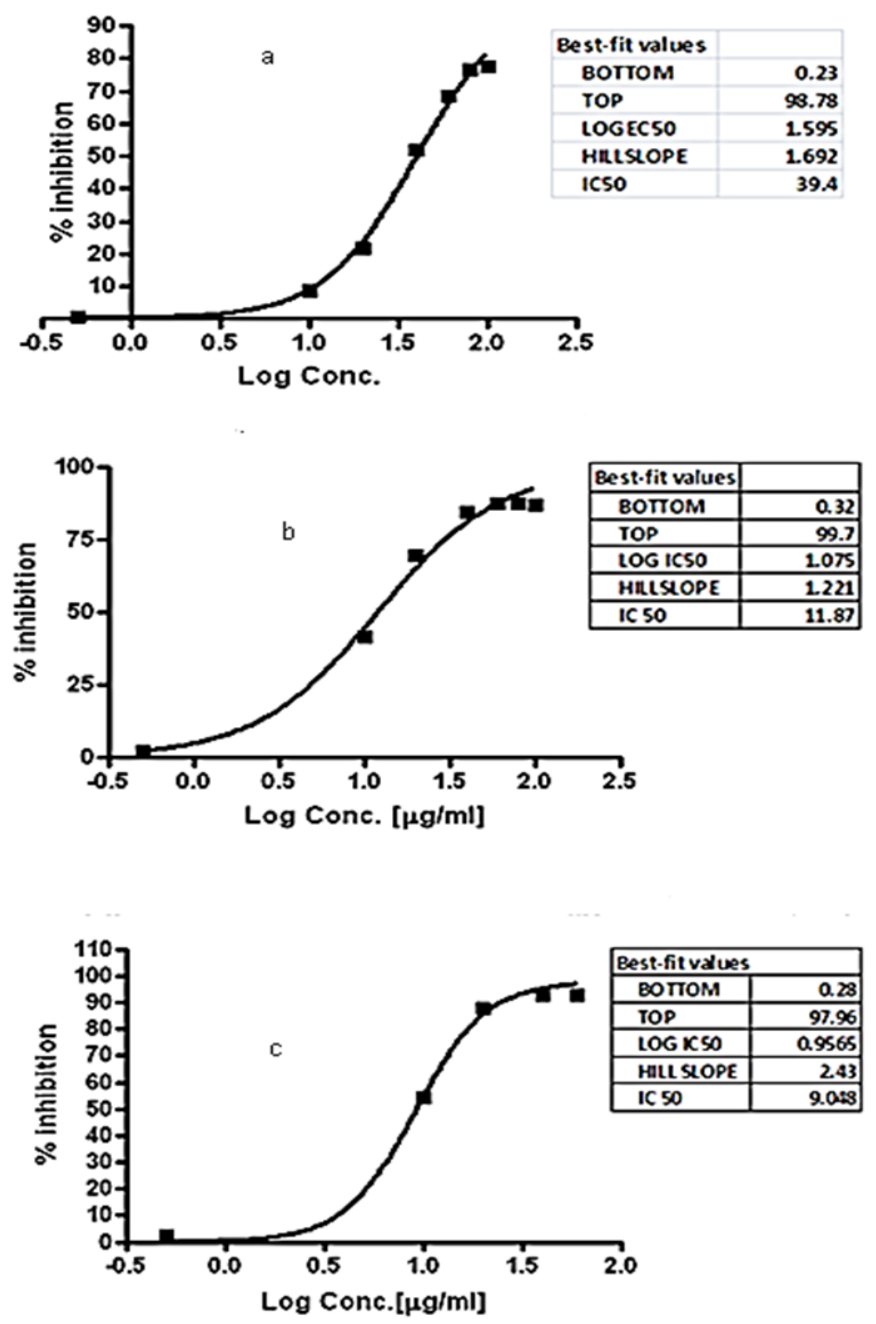

Figure 2 Dose response curve ( $\alpha$ amylase inhibition assay) for a) methanolic, b) dichloromethane and c) hexane extract of Garcinia mangostana

In a study where different fractions of Garcinia mangostana plant were tested, polyphenols rich fraction was found to have highest inhibitory activity with $\mathrm{IC}_{50}$ of $5.4 \mu \mathrm{g} / \mathrm{mL}$ but total phenolic content was not having any correlation with the alpha amylase inhibitory activity. Oligomeric proanthocyanidins were the main compounds present in the fraction having high inhibitory activity (Loo $\boldsymbol{e t}$ al. 2007). In another study, the ethanol extract of the aerial parts of Salvia Virgato showed an Inhibitory activity on pancreatic $\alpha$ - amylase. Further the study led to Identification of the active flavone, chrysoeriol. (Nickavar et al., 2013). Tea polyphenols $(0.05 \mathrm{mg} / \mathrm{ml})$ have also inhibited $\alpha$ amylase with $61 \%$, which also suggested that tea polyphenol might possess antinutritional properties (He $\boldsymbol{e t}$ al. 2006). In the present study Garcinia mangostana has been found to have a very significant activity against alpha amylase enzyme and has already been reported to have a very good antioxidant activity. Thus the correlation between the two activities can be a good area to explore.

\section{Alpha glucosidase inhibition assay}

Methanol, dichloromethane and hexane extracts of Garcinia mangostana were assayed for alpha glucosidase inhibition assay with Acarbose as standard and did not show any significant inhibition. Berry extracts rich in polyphenols inhibited alpha amylase and alpha glucosidase (Ashley et al., 2012). Anthocyanins inhibit alpha-glucosidase activity and thus, is helpful in reducing the blood glucose levels. Simultaneously, ellagitannins are found to inhibit alpha amylase enzyme. Thus intake of berries which are rich both in anthocyanins and ellagitannins can cause a cumulative effects in digestion of carbohydrates (McDougall et al. 2005). Potent inhibitory compounds have also been investigated by quantifying the polyphenolic composition in effective and less effective extracts. Modulation of their glycemic response has been studied in humans also to prove the authenticity of their effectiveness. Polyphenols and phlorotannins (PHT) from brown seaweeds have also been found to inhibit $\alpha$ amylase and $\alpha$ glucosidase enzyme. PHT extracted from Ascophyllum nodosum and Fucus vesiculosus inhibited $\alpha$ amylase and $\alpha$ glycosidase with very low $\mathrm{IC}_{50}$ values which is comparable to other plant polyphenols (Roy et al., 2011). Orlistat induced weight loss mechanism behind which is lipid inhibition has generated interest of scientists in finding nutraceuticals that inhibit the breakdown of macromolecules such as carbohydrates and fats. Acarbose and phaseolamine have been reported to have some promising results relating to weight loss (Tucci et al., 2010). Thus, the pericarp of Garcinia mangostana, which is a good source of alpha amylase inhibitors as well as have a very significant antioxidant activity, can be targeted as therapeutic drug in future. Many diseases related to macromolecules digestion can be solved by deciphering such compounds which can delay nutrient digestion and thus does not allow them to get absorbed fast in the body, helping in curing diseases associated with them.

\section{CETP inhibition assay}

Methanol, dichloromethane and hexane extracts of Garcinia mangostana were analyzed for CETP inhibition assay at various concentrations $(10-100 \mu \mathrm{g} / \mathrm{ml})$ by using CETP inhibition drug screening kit. Similar to $\alpha$ amylase inhibition results, it was found that hexane extract gave a remarkable inhibition of $85.67 \%$. Due to this significant result, the extract was taken for dose response study and an $\mathrm{IC}_{50}$ of $10.89 \mu \mathrm{g} / \mathrm{ml}$ was obtained (Fig 3).

\section{CETP inhhibition assay for GMH Extract}

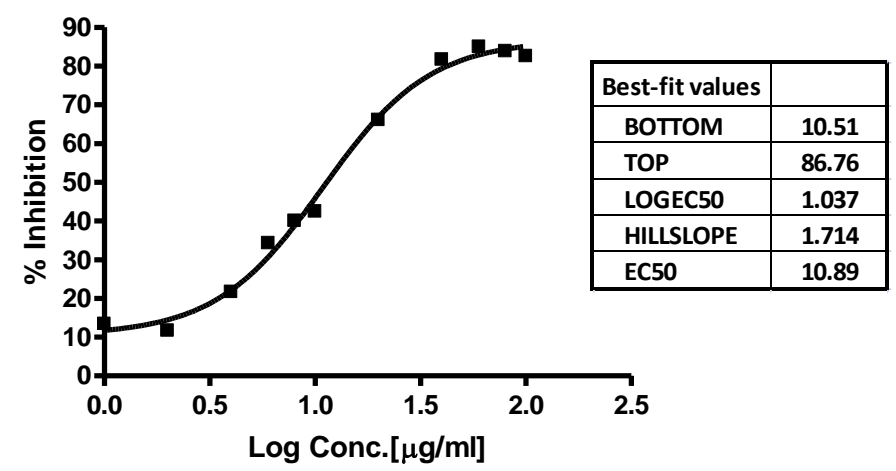

Figure 3 Dose response curve (CETP Inhibition assay) for hexane extract of Garcinia mangostana

\section{CETP Inhibition assay for alpha mangoteen}

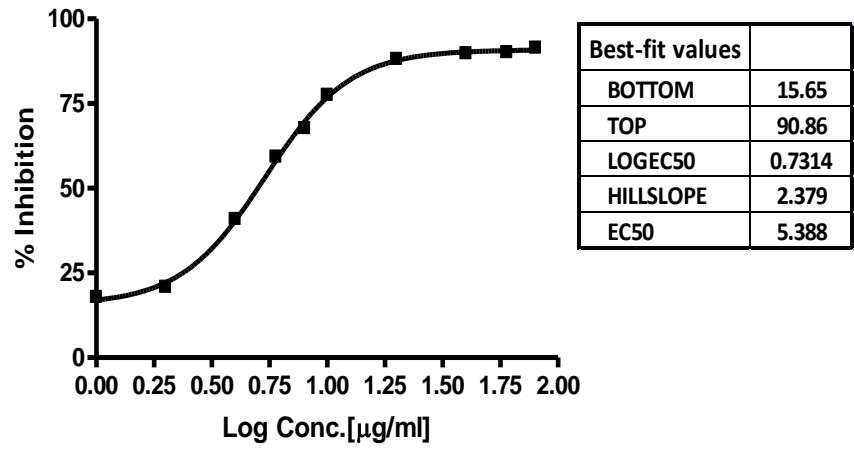

Figure 4 Dose response curve (CETP Inhibition assay) for reference standard $\alpha$ mangosteen

In order to confirm that $\alpha$ mangosteen is the potent compound, CETP inhibition assay was again performed with the reference standard and below is the dose 
response curve (Fig 4) obtained for the different concentrations of $\alpha$ mangosteen A significant $\mathrm{IC}_{50}$ of $5.388 \mu \mathrm{g} / \mathrm{ml}$ was obtained which confirmed that the potent active compound responsible for CETP inhibition is $\alpha$ mangosteen. The $\mathrm{IC}_{50}$ for hexane extract is $10.89 \mu \mathrm{g} / \mathrm{ml}$ which is in the range of two fold and thus acceptable. Till date, the most active natural CETP inhibitor, and [10] dehydrogingerdione, has been found from the rhizomes of Zingiber officinale Roscoe. This active compound inhibited cholesteryl ester transfer protein with $\mathrm{IC}_{50}$ values of $35 \mu \mathrm{M}$ and it was compared against a positive control DSphingosine that gave an $\mathrm{IC}_{50}$ of $11.5 \mu \mathrm{M}$. Very few compounds isolated from the natural sources have been identified as CETP inhibitors among which dehydrogingeridione was found to have the strongest inhibitory activity agains cholesteryl ester transfer protein (Choi et al., 2011). Four ceramides which have been isolated from the gorgonian Acabaria undulata and $\mathrm{N}, \mathrm{N}$ dimethylsphingosine found to inhibit cholesteryl transfer protein with $\mathrm{IC}_{50}$ values of 46.8, 57.3, 86.3, 65.6 and $6.3 \mu \mathrm{m}$ (Jeong et al., 1997). Xanthohumol, prenylated chalcone also showed the highest inhibition against cholesteryl ester transfer protein. Naringenin chalcone showed weak cholesteryl ester transfer protein inhibition compared with xanthohumol. Isoxanthohumol and Naringenin significantly decreased the inhibitory activity. According to these results, it was concluded that the prenyl group and chalcone structure of xanthohumol were responsible for the cholesteryl ester transfer protein inhibitory activity. Xanthohumol had a potent cholesteryl ester transfer protein inhibitory property with an $\mathrm{IC}_{50}$ of $31.2 \mu \mathrm{g} / \mathrm{ml}(88.0 \mu \mathrm{m})$. The mechanism behind was noncompetitive and chalcone structure and prenyl group were found to be essential for its inhibitory action (Hirata et al., 2012). The observation from Japanese populations with CETP deficiency has led to the conclusion that cholesteryl ester transfer protein inhibiting drugs may elevate concentration of high density lipoprotein and thus decrease cardiovascular risk and atherosclerosis (Barter et al., 2006 and 2007). Thus from the present study, where alpha mangosteen has been found as a novel inhibitor of cholesteryl ester transfe protein. As the screening was performed by biochemical assay, further if taken up for analysis in human plasma, the results then can be translated into the possibility of a drug as cholesteryl ester transfer protein inhibitor derived from a natural source and can be a promising cure for certain diseases.

\section{Thin layer chromatography}

Chloroform and ethyl acetate (80:20) solvent system gave the best result in silica plates. It showed one major band with the separation of one particular compound which made it easier for further analysis of HPLC. One prominent band in Chloroform: ethyl acetate (80:20) solvent system indicated one major compound in the hexane extract of Garcinia mangostana pericarp. Along with this majorly present compound some other compounds were also suspected to be present in small quantity.

\section{High performance Liquid Chromatography (HPLC)}

HPLC was further used for analyzing the compounds of the hexane extract of Garcinia mangostana pericarp. Result showed one major peak prominent at RT 16.28 min along with some other minor compounds (Fig 5).

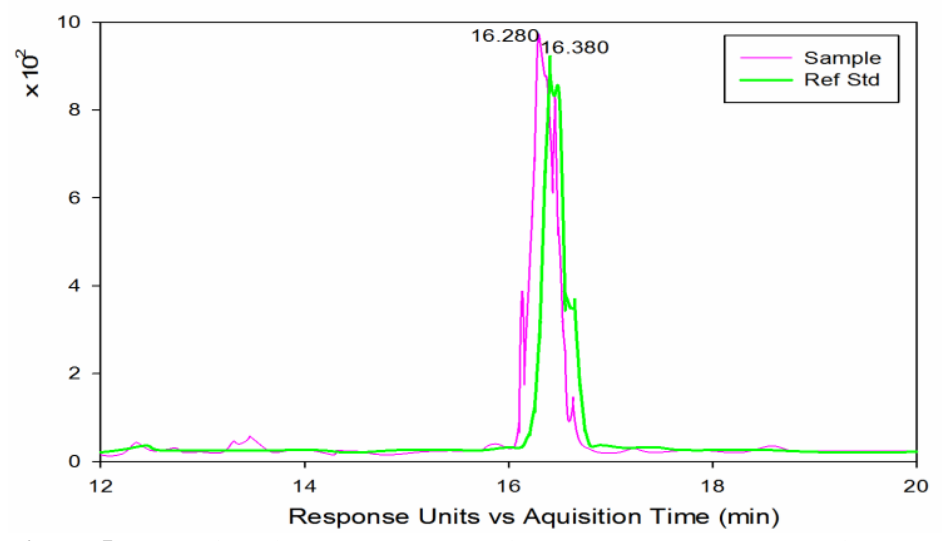

Figure 5 Comparison between HPLC results of Garcinia mangostana hexane extract and $\alpha$ mangosteen

Method for detection and quantification of $\alpha$ mangosteen in plasma consists of reversed phase high performance liquid chromatography (C18 reversed phase column) with ultraviolet detection. The mobile phase consisted methanol and water $(95: 5 \% \mathrm{v} / \mathrm{v})$ at a flow rate of $1.0 \mathrm{ml} / \mathrm{min}$. Under these conditions, the retention time for $\alpha$ mangosteen was $10.84 \mathrm{~min}$ (Syamsudin et al., 2010). In another study, chromatographic separation was done on a Hypersil BDS C-18 column using a gradient mobile phase (70-80\% acetonitrile in $0.1 \% \mathrm{v} / \mathrm{v}$ ortho phosphoric acid). The flow rate used was $1 \mathrm{ml} / \mathrm{min}$ with UV detection at $320 \mathrm{~nm}$ where two extracts showed similar pattern and a major peak of $\alpha$ mangosteen was obtained for which retention time was 16.32 min (Pothitirat and Gritsanapan, 2009). It has been found that acetone and water (80:20) is an efficient solvent system to extract a wide variety of xanthones. Subsequent to which HPLC analysis was done using C-18 reverse phase column and a 30 min gradient of 65 $90 \%$ methanol in $0.1 \%$ formic acid solvent system was found effective to separate different xanthones with UV detection at $254 \mathrm{~nm}$. Various xanthones and 9 hydroxycalabaxanthone, $\alpha$ mangosteen, $\beta$ mangosteen, gartanin, 8 desoxygartanin and 3 mangosteen were identified (Edward, 2007). Thus this method proved to be a good method for analysis of xanthones in the pericarp of Garcinia mangostana. Fig 5 illustrates the comparative HPLC results of hexane extract of Garcinia mangostana and $\alpha$ mangosteen where the peak in pink colour represents the hexane extract and green color represents alpha mangosteen. A $310 \mathrm{~nm}$, the retention time of $\alpha$ mangosteen was found to be at $16.38 \mathrm{~min}$ which is very much near to the result obtained for the sample i.e. $16.28 \mathrm{~min}$. In this case, under the same chromatographic conditions similar retention time has been achieved.

\section{Liquid Chromatography Mass Spectrometry (LC-MS)}

Fig 6 shows the LC-MS results for Garcinia mangostana hexane extract in negative mode. The chromatogram clearly indicated the presence of $\alpha$ mangosteen in the sample along with other xanthones such as Garcinone E etc. Result illustrated green color peak for hexane extract of Garcinia mangostana and pink color for standard $\alpha$ mangosteen. LC-MS results for the sample were found comparable with reference standard results. $M / z$ value for sample was found to be 409.2 compared to $\alpha$ mangosteen M.W. 409.3 (Zarena et al., 2009). Thus it can be concluded that $\alpha$ mangostin was present as major compound in the sample and might be responsible for potent activity.

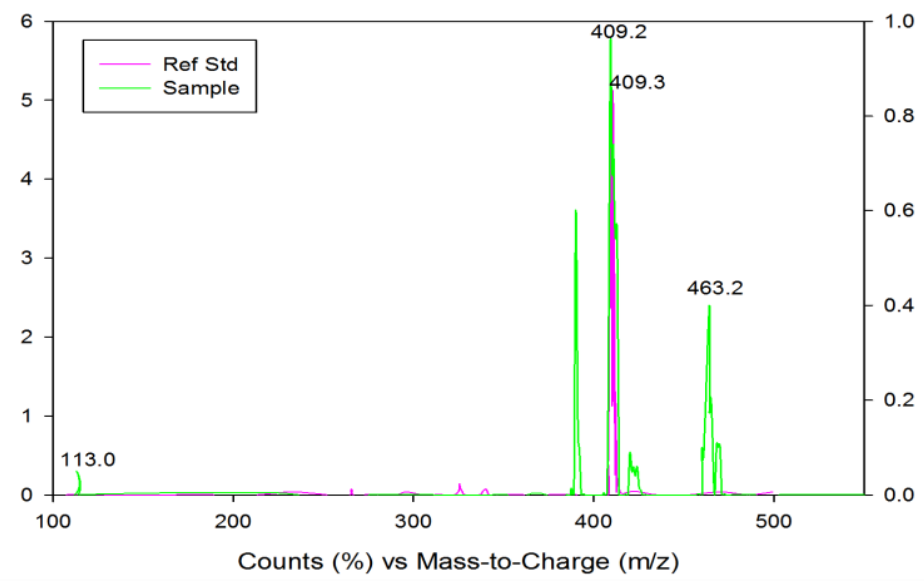

Figure 6 Comparison between LC-MS results of Garcinia mangostana hexane extract and $\alpha$ mangosteen

To determine the concentration of alpha mangosteen for toxicological investigation of a nutraceutical formulation, the LC separation was developed on a Phenomenex Gemini C-18 column using a 12 min. gradient consisting of $1 \%$ formic acid and methanol: acetonitrile $(20: 80, \mathrm{v} / \mathrm{v})$. In a single $35 \mathrm{~min}$ chromatographic run, ethyl acetate, acetone and hexane extracts of mangostin peel were analysed by HPLC (Xiuhong et al., 2007). The polarity of the solvents played a major role in the extraction and purification of a compound from a complex mixture. This requires a comprehensive study about the type of compounds present in the raw material. Seven xanthones 3-isomangostin- $m / z$ 427, 8-desoxygartanin- $m / z$ 379, gartanin- $m / z$ 395, $\alpha$-mangostin- $m / z \quad 409$ garcinone $\mathrm{E}-\mathrm{m} / \mathrm{z}$ 463, 9-hydroxycalabaxanthone- $\mathrm{m} / \mathrm{z} 407$ and $\beta$-mangostin $-\mathrm{m} / \mathrm{z}$ 423 were detected with $\alpha$ mangostin being the predominant compound in all the extracts. $\alpha$ mangostin has $\mathrm{m} / \mathrm{z}$ value of 409 in the negative mode and it shows $\mathrm{m} / \mathrm{z}$ value of 411 in the positive mode which shows that it is a kind of neutral compound which gives reading in both the modes (Zarena et al., 2009).

\section{CONCLUSION}

The focus of the study was to discover novel natural inhibitors of digestive and metabolic enzymes which can be taken up for further clinical trials and can be targeted as therapeutic drugs in future. Among many plant extracts tested for the inhibitory activity, not many have been found to show the potent activity. In the current study, the methanolic, dichloromethane and hexane extracts of Garcinia mangostana was found to be effective against alpha amylase enzyme and thus can be targeted as a therapeutic drug for Diabetes. The hexane extract of Garcinia mangostana pericarp has shown potent activity against cholesteryl ester transfer protein. The findings of the study conclude that the pericarp of Garcinia mangostana is a remarkable inhibitor of $\alpha$ amylase enzyme with the most effective hexane extract of $\mathrm{IC}_{50} 9.048 \mu \mathrm{g} / \mathrm{ml}$. The pericarp of Garcinia mangostana is also a remarkable inhibitor of cholesteryl ester transfer protein 
with the hexane extract of $\mathrm{IC}_{50} 10.89 \mu \mathrm{g} / \mathrm{ml}$. The most bioactive compound present in the pericarp of Garcinia mangostana is responsible for its potent activity to inhibit cholesteryl ester transfer protein with an $\mathrm{IC}_{50}$ of $5.388 \mu \mathrm{g} / \mathrm{m}$ which is also comparable to the hexane extract of Garcinia mangostana pericarp. The pericarp of Garcinia mangostana is a rich source of xanthones having antidiabetic and anticholesterol activity. The pericarp of Garcinia mangostana can be further purified to identify the active compound responsible for its inhibitory activity against alpha amylase enzyme. $\alpha$ mangosteen can be taken for further clinical trials to prove the results for CETP inhibition in animal studies. Application of alpha mangosteen in food products and beverages can be done to develop functional foods.

Acknowledgments: This research was financially supported by the Tha Government Scholarship (Queens Scholarship) at Asian Institute of Technology, Thailand. Lab facilities and technical assistance was provided for anima experiments at G7 Synergon, India and animals were borrowed from Aacharya Institute of Technology, India

\section{REFERENCES}

ASAI, F., TOSA, H., TANAKA, T., IINUMA, M.A. 1995. Xanthone from pericarps of Garcinia mangostana. Photochemistry, 39(4), 943-944. http://dx.doi.org/10.1016/0031-9422(95)00042-6

BARTER, P.J., CAULFIELD, M., \& ERIKSSON, M. 2007. Effects of Torcetrapib in patients at high risk for coronary events. The New England Journal of Medicine, 357, 2109-22. http://dx.doi.org/10.1016/j.jvs.2008.02.014

BARTER, P.J., \& KASTELEIN, J.J. 2006. Targeting Cholesteryl Ester Transfer Protein for the Prevention and Management of Cardiovascular Disease. Journal of the American College of Cardiology, 47,492-499. http://dx.doi.org/10.1016/j.jacc.2005.09.042

CHAIRUNGSRILERD, N., TAKEUCHI, K., OHIZUMI, Y., NOZOE, S., \& OHTA, T. 1996. Mangostanol, a prenyl xanthone from Garcinia mangostana Phytochemistry, 43(5), 1099-1102. http://dx.doi.org/10.1016/s00319422(96)00410-4

CHOI, S.Y., PARK, G.S., LEE S.Y., KIM, J.Y., KIM, Y.K. 2011. The conformation and CETP inhibitory activity of [10]-Dehydrogingerdione isolated from Zingiber officinale. Archives of Pharmacol Research, 34(5), 727-731. http://dx.doi.org/10.1007/s12272-011-0505-5

GHASEMZADEH, A., JAAFAR, H.Z.E., RAHMAT, A. 2010. Antioxidan activities, total phenolics and flavonoids content in two varieties of Malaysia young ginger (Zingiber officinal Roscoe). Molecules, 15, 4324-4333. http://dx.doi.org/10.3390/molecules15064324

HE, Q., LV, Y., YAO, K. 2006. Effects of tea polyphenols on the activities of aamylase, pepsin, trypsin and lipase. Food Chemistry, 101, 1178-1182 http://dx.doi.org/10.1016/j.foodchem.2006.03.020

HIRATA, H., TAKAZUMI, K., SEGAWA, S., OKADA, Y., KOBAYASHI, N., SHIGYO, T., CHIBA, H. 2012. Xanthohumol, a prenylated chalcone from Humulus lupulus L., inhibits cholesteryl ester transfer protein. Food Chemistry, 134(3), 1432-1437. http://dx.doi.org/10.1016/j.foodchem.2012.03.043

HUANG, Y.L., CHEN, C.C., CHEN, Y.J., HUANG, R.L., SHIEH, B.J. 2001 Three Xanthones and a Benzophenone from Garcinia Mangostana. Journal of Natural Products, 64(7), 903-6. http://dx.doi.org/10.1021/np000583q

JEONG, T.S., AHN, J.A. , KIM, Y.K., BOK, S.H., KWON, B.M. 1997. CETP inhibitory activity of ceramides, isolated from the gorgonian Acabaria Undulata. Biorganic and Medicinal Chemistry, 7, 1481-1482. http://dx.doi.org/10.1016/s0960-894x(97)00248-5

LEONTOWICZ, M., LEONTOWICZ, H., DRZEWIECKI, J., JASTRZEBSKI, Z., HARUENKIT, R., POOVARODOM, S., YONG-SEO, P., JUNG, S.T., KANG, S.K., TRAKHTENBERG, S., GORINSTEIN, S. 2007. Two exotic fruits positively affect rat's plasma composition. Food Chemistry, 102(1), 192-200. http://dx.doi.org/10.1016/j.foodchem.2006.05.046

LOO, A.E.K., HUANG, D. 2007. Assay-guided fractionation study of $\alpha$-amylase inhibitors from Garcinia mangostana pericarp. Journal of Agricultural and Food Chemistry, 55, 9805-9810. http://dx.doi.org/10.1021/jf071500f

MCDOUGALL, G.J., STEWART, D. 2005. The inhibitory effects of berry polyphenols on digestive enzymes. Bio factors, 23, 189-95. http://dx.doi.org/10.1002/biof.5520230403

MERTES, G. 2001. Efficacy and safety of Acarbose in the treatment of Type 2 diabetes: data from a 5-year surveillance study. Diabetes Research and Clinical Practice, 52, 193-204. http://dx.doi.org/10.1016/s0168-8227(98)00045-X

MISHRA, H., DWIVEDI, B.K., MEHTA, D., MEHTA, B.K., JAIN, D.C. (2009). Development and validation of high performance thin-layer chromatographic method for determination of $\alpha$ mangostin in fruit pericarp of mangosteen plant (Garcinia mangostana 1.) using ultraviolet visible detection. Records of Natural Products, 4178-186.

MOHAMMAD, A., BHAWANI, S.A., SHARMA, S. 2010. Analysis of Herbal Products by Thin-layer Chromatography: A Review. International Journal of Pharma and Bio Sciences, 1(2), 1-50.
NADKARNI, K.M., NADKARNI, A.K. 1999. Indian Materia Medica - with Ayurvedic, Unani-Tibbi, Siddha, Allopathic, Homeopathic, Naturopathic and Home remedies. Vol.1. Popular Prakashan Private Ltd., Bombay, India. ISBN No. 81-7154-142-9.

NICKAVAR, B., ABOLHASANI, L., IZADPANAH, H. 2013. Bioactivityguided Separation of an $\alpha$-Amylase Inhibitor Flavonoid from Salvia virgata. Iran Journal of Pharmaceutical Research, 12(1), 57-61.

POTHITIRAT, W., GRITSANAPAN, W. 2009. HPLC Quantitative analysis method for the determination of $\alpha$-Mangostin in Mangosteen Fruit rind extract. Thai Journal of Agricultural Science, 42, 7-12.

ROY, MARIE-CLAUDE, ANGUENOT, R., FILLION, C., BEAULIEU, M. BERUBE, J., RICHARD, D. 2011. Effect of a commercially-available algal phlorotannins extract on digestive enzymes and carbohydrate absorption in vivo. Food Research International, 44(9), 3026-29. http://dx.doi.org/10.1016/j.foodres.2011.07.023

SUKSAMRARN, S., SUWANNAPOCH, N., RATANANUKUL, P., AROONLERK, N., SUKSAMRARN, A. 2002. Xanthones from the green fruit hulls of Garcinia mangostana. Journal of Natural Products, 65(5), 761-3.

SUKSAMRARN, S., KOMUTIBAN, O., RATANANUKUL, P., CHIMNOI, N., LARTPORNMATULEE, N., SUKSAMRARN, A. 2006. Cytotoxic prenylated xanthones from the young fruit of Garcinia mangostana. Chemical and Pharmaceutical Bulletin, 54(3), 301-305 http://dx.doi.org/10.1002/chin.200634209

SYAMSUDIN, FAIZATUN, LESTARI, R. 2010. HPLC Analysis and pharmacokinetic study of Mangostin after orally administration in rats International Journal of Pharma and Bio Sciences, 1(1), 1-7.

TADERA, K., MINAMI, Y., TAKAMATSU, K., MATSUOKA, T. 2006 Inhibition of $\alpha$-glucosidase and a-amylase by flavonoids. Journal of Nutritional Science and Vitaminology, 52, 149-153. http://dx.doi.org/10.3177/jnsv.52.149

TUCCI, S.A., BOYLAND, E.J., HALFORD, J.C. 2010. The role of lipid and carbohydrate digestive enzyme inhibitors in the management of obesity: a review of current and emerging therapeutic agents. Diabetes Metabolic Syndrome and Obesity: Targets and Therapy, 125 143. http://dx.doi.org/10.2147/dmsott.s7005

WALKER, E.B. 2007. HPLC analysis of selected xanthones in mangosteen fruit. $\begin{array}{llll}\text { Journal of Separation } & \text { Science, } & 30, & 1229-1234\end{array}$ http://dx.doi.org/10.1002/jssc.200700024

XIUHONG, J., A., BHARATHI, A.A., IKHLAS, A.K. 2007. Quantitative and qualitative determination of six xanthones in Garcinia mangostana L. by LC PDA and LC ESI-MS. Journal of Pharmaceutical and Biomedical Analysis, 43, 1270-1276. http://dx.doi.org/10.1016/j.jpba.2006.10.018

ZADERNOWSKI, R., CZAPLICKIA, S., NACZK, M. 2009. Phenolic acid profiles of mangosteen fruits (Garcinia mangostana). Food Chemistry, 112, 685689. http://dx.doi.org/10.1016/j.foodchem.2008.06.030

ZARENA, A.S., SANKAR, U. 2009. Screening of xanthone from mangosteen (Garcinia mangostana L.) peels and their effect on cytochrome c reductase and phosphomolybdenum activity. Journal of Natural Products, 2, 23-30. 